УДК 616.314-76:616-036.8:303.62

\title{
ОЦІНКА ЭФЕКТИВНОСТІ ОРТОПЕДИЧНОГО ЛІКУВАННЯ ПАЦІЄНТІВ ЗІ ЗНІМНИМИ КОНСТРУКЦІЯМИ ЗУБНИХ ПРОТЕЗІВ НА ПІДСТАВІ ДАНИХ ЯКОСТІ ЖИТТЯ
}

\author{
І.В. Янішен, К.Ю. Андрієнко, О.О. Бережна, А.В. Погоріла, Л.Г. Салія \\ ХаркіВський національний медичний університет
}

\begin{abstract}
В даній статті представлена оцінка ефективності ортопедичного лікування пацієнтів з частковою та повною відсутністю зубів на підставі даних якості життя, виявлених у результаті комплексу клінічних досліджень за допомогою аналізу ортопедичних конструкцій зубних протезів.

Було проведено клінічне обстеження та суб'єктивний аналіз пацієнтів, що звернулися з метою протезування знімними ортопедичними конструкціями. Для визначення соціальної характеристики пацієнтів і рівня їх якості життя та формування індивідуальної анкети-опитувальника були застосовані спеціальні методи дослідження. Стандартизація процедури збору даних забезпечувалася з використанням анкет-опитувальників.

Отримані дані піддавалися процесу шкалювання, перетворюючись в бали. Відповіді на питання оцінювалися за 5-бальною системою. Якість життя пацієнтів за всіма шкалами спеціального опитувальника істотно змінювалась в сторону поліпшення через місяць та пів року після лікування i зберігалася в часі, що пояснює стабільність лікувального ефректу, що визначається правильністю обраної ортопедичної конструкції та якісно проведеним лікуванням.

Таким чином, якість життя пацієнтів являє собою далеко не останню позицію у якісному ортопедичному лікуванні та ї̈ необхідно враховувати в практичній діяльності лікарів-стоматологівортопедів.

Ключові слоВа: якість життя, часткові знімні протези, повні знімні протези, поріВняльний аналіз, анкета-опитуВальник, статистичні дані.
\end{abstract}

Дослідження $€$ фррагментом комплексної науководослідної програми Харківського національного медичного університету МОЗ України, кафедри ортопедичної стоматології «Характер, структура та лікування основних стоматологічних захворювань» (№ держ. реєстрації 0116U004975; 2016-2018рр.).

Вступ. Здоров'я - це одна 3 найважливіших життєвих цінностей людини, запорука ії благополуччя і довголіття, що дає людям відчуття повноти життя, можливість здійснювати дії, що викликають задоволення, відчуття контролю над власним життям і її умовами [8]. Стоматологічне здоров'я - це стан, який дозволяє людині функціонально харчуватися і покращити комунікативні фрункції, відновити естетичну функцію порожнини рота і обличчя, підвищити самооцінку. На сучасному етапі розвитку суспільства надання стоматологічної допомоги населенню повинно мати головною метою досягнення та підтримання функціонуючої, безболісної, естетичної та соціально прийнятної ситуації в порожнині рота протягом усього життя у більшості людей.

Для визначення ефективності заходів, спрямованих на поліпшення та збереження здоров'я населення, в даний час стали використовувати такий кількісний показник, як якість життя (ЯЖ) [6].
Поняття «якість життя» давно стало звичним у соціологів та поступово стало загальноприйнятим терміном. Їм позначають сукупність рис і властивостей особистості і суспільства, особливості умов їх життя, здоров'я, роботи, проживання, харчування, відпочинку, стану зовнішнього середовища.

Таким чином, «якість життя» має дві сторони - суб'єктивну, що залежить від самої особистості, і об'єктивну, обумовлену ступенем розвитку суспільства, держави, природними фракторами, рівнем цивілізації, використовуваними благами.

На думку А.А. Новик та Т.І. Іонової, особливо велике значення має дослідження якості життя в медицині. Ця концепція дозволила повернутися до принципу клінічної практики «лікувати не хворобу, а хворого» $[1,7]$.

У сучасній ортопедичній стоматології питання якості життя, пов'язане напряму зі здоров'ям пацієнта, займає одну з актуальних позицій у якісному лікуванні. Цьому питанню присвячена велика кількість досліджень, що описані у вітчизняній та закордонній літературі. Дослідження якості життя, пов'язаного зі здоров'ям, дозволяє вивчити вплив захворювання і лікування на показники якості життя хворої людини, оцінюючи всі складові здоров'я - фізичне, психологічне і соціальне функціонування. 
За останні роки було розроблено понад 10 основних індексів, що дозволяють оцінити вплив стоматологічного здоров'я на якість життя. Найбільш використовуваними інформативними індексами при проведенні досліджень прийнято вважати наступні.

1. Вплив стоматологічного статусу на повсякденне життя пацієнта - Dental Impact on Daily Living (DIDL) (A. Leao, A. Sheiham, 1996);

2. Ступінь важливості стоматологічного здоров'я - Oral Health Impact Profile (OHIP) (G. Slade, J. Spenser, 1994);

3. Взаємозв'язок стоматологічного здоров'я та якості життя - Oral Health - Related Quality of Life (OHQoL) (N. Kressin, A. Spiro, 1996), для вимірювання різного впливу стоматологічного статусу на повсякденні функції.

Вищезазначені індекси являють собою об'єктивні засоби вимірювання, що оцінюють стоматологічне здоров'я в термінах його впливу на якість життя. Кожен $з$ цих індексів призначений для вимірювання частоти, ступеня впливу стоматологічних проблем на функціональне і соціально-психологічне благополуччя.

Таким чином, оцінка якості життя пацієнтів необхідна не тільки для досягнення запланованого результату реабілітації, але і для оцінки есрективності застосовуваних схем та технологій ортопедичного лікування.

Мета дослідження - оцінка ефективності ортопедичного лікування пацієнтів з частковою та повною відсутністю зубів на підставі даних якості життя, виявлених у результаті комплексу клінічних досліджень за допомогою аналізу ортопедичних конструкцій зубних протезів та розробки необхідних рекомендацій.

Матеріали та методи. Дослідження було проведено на кафедрі ортопедичної стоматології на базі Університетського стоматологічного центру Харківського національного медичного університету. Протягом 2016-2018 років було проведено клінічне обстеження та суб'єктивний аналіз 160 пацієнтів, які звернулися з метою протезування знімними ортопедичними конструкціями.

Основними критеріями вибору ортопедичних пацієнтів у дослідженні якості життя становили: розподіл за статевою ознакою: чоловіки /жінки = 1:1; вік пацієнтів - від 40 до 80 років; регіон проживання -
Харків та область; часткова та повна відсутність зубів на верхній і нижній щелепах; топографія дефектів зубних рядів за класифікацією Кеннеді (I, II, III, IV класи), беззубих щелеп згідно класифікацій Келлера, Шредера, стану слизової оболонки за Супплі; методи ортопедичного лікування (часткові знімні, повні знімні) на попередніх та кінцевих етапах надання спеціалізованої ортопедичної допомоги [13].

Усі етапи були виконані 3 мінімальними психологічними втратами з боку пацієнтів. Пацієнти були повністю інформовані про мету та методи дослідження, про потенційні користь і ризик, а також можливий дискомфорт при проведенні діагностики і лікування. Виконані всі етичні вимоги у відповідності підтримки конфріденційності отриманої інформації в процесі дослідження [3, 7].

Для визначення соціальної характеристики пацієнтів і рівня їх якості життя та фрормування індивідуальної анкети-опитувальника нами були застосовані спеціальні методи дослідження: збір даних, формування бази даних та шкалування результатів опитувальників; статистичні методи обробки даних (використання інформативних індексів); аналіз та інтерпретація отриманих результатів [9].

Клінічні дані були отримані шляхом проведення розширеного стоматологічного обстеження із застосуванням «Карти для оцінки стоматологічного статусу» згідно ВООЗ, 1995 р. Результат клінічного обстеження мав значення для подальшої діагностики і вибору методу ортопедичного лікування $[2,5,11]$.

Стандартизація процедури збору даних забезпечувалася уніфікованим характером обстеження і реєстрації епідеміологічного матеріалу з використанням анкет-опитувальників: загальної анкети якості життя WHOQoL-100 (WHOQoL Group, 1993) i спеціалізованої стоматологічної анкети якості життя ОШР-14 (G. Slade, 1993), та модифікованої нами анкети-опитувальника.

Результати досліджень. Розподіл обстежених пацієнтів було обумовлено специфічними відмінностями клінічних ознак стану часткової або повної відсутності зубів залежно від статі та різних вікових періодів, дані яких представлені в табл. 1. Кількісні показники відображені наступним чином: чоловіки з частковою втратою зубів - 31 пацієнт

Таблиця 1. Кількісний показник хворих з частковою та повною відсутністю зубіВ за статтю та Віком

\begin{tabular}{|c|c|c|c|c|c|c|c|}
\hline \multirow{4}{*}{$\begin{array}{c}\text { № } \\
\text { підгрупи }\end{array}$} & \multirow{4}{*}{ Вік пацієнта } & \multicolumn{6}{|c|}{ Кількісний показник } \\
\hline & & \multicolumn{2}{|c|}{ Чоловіки } & \multicolumn{2}{|c|}{ Жінки } & \multicolumn{2}{|c|}{ Загалом } \\
\hline & & \multicolumn{6}{|c|}{ Відсутність зубів } \\
\hline & & часткова & повна & часткова & повна & часткова & повна \\
\hline 1. & 40-50 років & 14 & 6 & 16 & 4 & 30 & 10 \\
\hline 2. & 50-60 років & 10 & 10 & 12 & 8 & 22 & 18 \\
\hline 3. & 60-70 років & 5 & 16 & 6 & 15 & 11 & 31 \\
\hline 4. & 70 років та старше & 2 & 18 & 6 & 14 & 8 & 32 \\
\hline \multicolumn{2}{|r|}{ Всього } & $31(19,4 \%)$ & $50(31,3 \%)$ & $40(25 \%)$ & $41(25,6 \%)$ & $71(44,4 \%)$ & $89(55,6 \%)$ \\
\hline
\end{tabular}


(19,4\% від загальної кількості обстежених), жінки з частковою втратою зубів - 40 пацієнтів (31,3\% від загальної кількості обстежених), чоловіки з повною адентією - 50 пацієнтів (25 \% від загальної кількості обстежених), жінки з повною адентією - 41 пацієнт (25,6\% від загальної кількості обстежених).

Критеріями виключення пацієнтів з досліджуваної групи становили: наявність важких соматичних захворювань, обтяжений алергологічний анамнез, поодиноко збережені зуби на верхній або нижній щелепах, раніше проведене ортопедичне лікування із застосуванням дентальних імплантатів, хронічний генералізований пародонтит в стадії загострення, пародонтоз, а також відмова самих пацієнтів від участі в дослідженні.

У результаті проведення анкетування досліджуваних пацієнтів 3 повної або часткової відсутності зубів нами була створена вибірка питань, що відображала актуальні проблеми якості життя у протезуванні частковими та повними знімними протезами. Зміст анкети-опитувальника наведений у табл. 2.

Опитувальник призначений для самостійного заповнення респондентом (пацієнтом), тобто відображає об'єктивну оцінку його самопочуття. Отримані дані піддавалися процесу шкалювання, перетворюючись в бали для спрощення статистичного аналізу. Відповіді на питання оцінювалися за 5-бальною системою [12].

Анкета складається з 22 питань і $є$ багатовимірним інструментом, що дозволяє отримувати як оцінку ЯЖ респондента в цілому, так і приватні оцінки по окремих сорерах і субсферах його життя. Описаний опитувальник включає в себе 3 інформаційних блоки, які $€$ значущими в аналізі динаміки критеріїв ЯЖ до та після ортопедичного лікування.

Відповідь на кожне питання залежно від ступеня вираженості описаної в ньому ситуації оцінювалася в балах від 1 до 5 (від найнижчого ступеня зацікавленості до найвищого).

Усім пацієнтам було проведено відповідне ортопедичне лікування повними та частковими знімними зубними протезами. При схожих клінічних ситуаціях в деяких випадках обирали різні методики ортопедичного лікування залежно від показань, особистих побажань і матеріальних можливостей кожного пацієнта на момент ортопедичного лікування $[4,10]$.

Оцінка в динаміці повноти збору даних дослідження якості життя хворих з частковою та повною відсутністю зубів була необхідною умовою та проводилась шляхом підрахунку суми балів кожного пацієнта за три етапи заповнення анкети. Реєстрація даних проводилася на трьох етапах дослідження - до початку лікування, через 1 та 6 місяців після лікування.

Оцінка отриманих результатів.

1. Відмінний результат - 100-110 балів (за одне опитування).

2. Хороший результат - 88-99 балів (за одне опитування).

3. Задовільний результат $-66-87$ балів (за одне опитування).
4. Незадовільний результат - 44-65 балів (за одне опитування).

5. Поганий результат - 22-43 бали (за одне опитування).

Найгірший рівень ЯЖ виявлено у пацієнтів 4-ї вікової підгрупи до та після ортопедичного лікування частковими знімними $(43,50 \pm 3,08$ та 47,32 $\pm 1,60$ балів) та повними знімними протезами $(56,00 \pm 2,38$ та $61,67 \pm 2,76$ балів).

Розглядаючи статистично значущі зміни серед пацієнтів, що використовували часткові знімні протези, найгірший рівень ЯЖ до та після лікування ви-

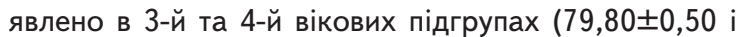
$64,50 \pm 0,33$ балів відповідно). Незважаючи на те, що показники змінилися в 1,28 рази в бік підвищення, кінцевий рівень ЯЖ, відображений через 6 місяців після лікування, залишився серед цих пацієнтів найгіршим. Жінки 3-ї та 4-ї підгруп мали рівень ЯЖ вище, ніж чоловіки, що становило $(85,8 \pm 1,9$ i 76,5 $\pm 3,6$ балів).

У 1-й підгрупі пацієнтів, що користувалися частковими знімними протезами, ЯЖ збільшилася

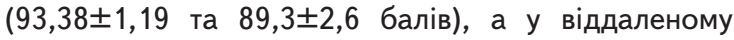
періоді (через 6 місяців) після ортопедичного лікування рівень ЯЖ був визначений як найкращий серед пацієнтів з даним видом протезів як у чоловіків,

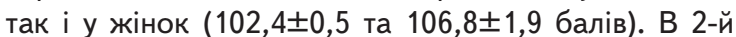
підгрупі позитивна динаміка складала $86,27 \pm 1,6$ і 90,27 $\pm 0,8$ відповідно.

Пацієнтам, яким ортопедичне лікування проводилося повними знімними протезами, рівень ЯЖ був різним. Найгірші значення до і після лікування було виявлено у 1-й віковій підгрупі $(40,3 \pm 0,90$ і 42,0土1,11 балів), водночас показники змінилися в 1,18 рази в бік підвищення. Найкращий рівень ЯЖ відзначався у

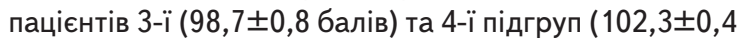
балів). До проведення ортопедичного лікування значення були приблизно однаковими.

Через 6 місяців після лікування рівень ЯЖ в 4-й підгрупі став декілька вище (у 1,14 рази) та у порівнянні з іншими підгрупами став максимальним

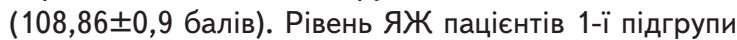
після лікування наблизився до значень 2-ї підгрупи, поліпшуючись в 0,9 рази $(61,60 \pm 0,14$ та $59,46 \pm 0,20$ балів відповідно).

Висновки. Результати проведеного дослідження показали, що до теперішнього часу майже відсутні дані про якість життя пацієнтів, що використовують знімні конструкції зубних протезів, незважаючи на високий рівень захворюваності, що визначає дану проблему як пріоритетну в системі ортопедичної стоматологічної реабілітації хворих з частковою та повною відсутністю зубів.

Залежно від того, якими протезами були відновлені дефекти зубних рядів, було виявлено, що початковий і кінцевий рівні якості життя були різними.

Спираючись на отримані статистично значущі результати з усіх питань анкети-опитувальника, можна оцінити рівень ЯЖ в цілому. У досліджуваних пацієнтів загальної вибірки середнє значення суми балів збільшилося після проведеного лікування в 
Ортопедична стоматологія

Таблиця 2. Анкета-опитувальник якості життя пацієнтів з повною або частковою відсутністю зубів при Виготовленні поВних та часткових знімних зубних протезів

\begin{tabular}{|c|c|c|c|c|c|c|}
\hline Блок & \multirow{2}{*}{ Питання } & \multicolumn{5}{|c|}{ Критерії відповідей (5-бальна шкала) } \\
\hline \multirow{5}{*}{ 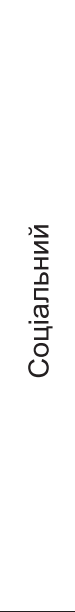 } & & 1 бал & 2 бали & 3 бали & 4 бали & 5 балів \\
\hline & $\begin{array}{l}\text { Як Ви оцінюєте } \\
\text { якість Вашого } \\
\text { життя? }\end{array}$ & погано & незадовільно & задовільно & добре & відмінно \\
\hline & $\begin{array}{l}\text { Наскільки Ви } \\
\text { задоволені станом } \\
\text { свого здоров'я? }\end{array}$ & погано & незадовільно & задовільно & добре & відмінно \\
\hline & $\begin{array}{l}\text { Наскільки здоровим } \\
€ \text { фізичне } \\
\text { середовище } \\
\text { навколо Вас? }\end{array}$ & погане & незадовільне & задовільне & добре & відмінне \\
\hline & $\begin{array}{l}\text { Як часто у Вас були } \\
\text { негативні } \\
\text { переживання, } \\
\text { наприклад, поганий } \\
\text { настрій, відчай, } \\
\text { тривога, депресія? }\end{array}$ & завжди & часто & нечасто & рідко & ніколи \\
\hline \multirow{6}{*}{ 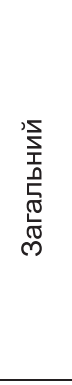 } & Обмеження функції & повне & майже повне & часткове & тимчасове & немає \\
\hline & Фізична біль & завжди & часто & нечасто & рідко & відсутня \\
\hline & $\begin{array}{l}\text { Психологічний } \\
\text { дискомфорт }\end{array}$ & завжди & часто & нечасто & рідко & відсутній \\
\hline & $\begin{array}{l}\text { Фізична } \\
\text { непрацездатність }\end{array}$ & повна & майже повна & часткова & тимчасова & відсутня \\
\hline & $\begin{array}{l}\text { Психологічна } \\
\text { непрацездатність }\end{array}$ & повна & майже повна & часткова & тимчасова & відсутня \\
\hline & $\begin{array}{l}\text { Соціальна } \\
\text { непрацездатність }\end{array}$ & повна & майже повна & часткова & тимчасова & відсутня \\
\hline \multirow{6}{*}{ 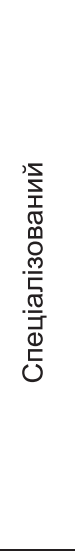 } & $\begin{array}{l}\text { Період адаптації до } \\
\text { протезу }\end{array}$ & погано & незадовільно & задовільно & добре & відмінно \\
\hline & $\begin{array}{l}\text { Фіксація конструкції } \\
\text { у порожнині рота }\end{array}$ & погана & незадовільна & задовільна & добра & відмінна \\
\hline & $\begin{array}{l}\text { Стан кісткової } \\
\text { тканини та слизової } \\
\text { оболонки під } \\
\text { протезом }\end{array}$ & поганий & незадовільно & задовільний & добрий & відмінний \\
\hline & $\begin{array}{l}\text { Наявність } \\
\text { запальних процесів } \\
\text { під протезом }\end{array}$ & дуже часто & часто & середнє & рідко & ніколи \\
\hline & $\begin{array}{l}\text { Попадання } \\
\text { залишків їжі під } \\
\text { протез }\end{array}$ & дуже часто & часто & середнє & рідко & ніколи \\
\hline & $\begin{array}{l}\text { Поломки/корекції } \\
\text { конструкції }\end{array}$ & дуже часто & часто & середнє & рідко & ніколи \\
\hline \multirow{6}{*}{ 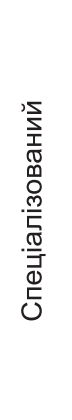 } & $\begin{array}{l}\text { Якість матеріалів } \\
\text { ортопедичної } \\
\text { конструкції }\end{array}$ & погана & незадовільна & задовільна & добра & відмінна \\
\hline & $\begin{array}{l}\text { Зручність } \\
\text { користування }\end{array}$ & погана & незадовільна & задовільна & добра & відмінна \\
\hline & Дикція пацієнта & погана & незадовільна & задовільна & добра & відмінна \\
\hline & $\begin{array}{l}\text { Використання } \\
\text { адгезивного } \\
\text { матеріалу } \\
\end{array}$ & дуже часто & часто & середнє & рідко & ніколи \\
\hline & Гігієна протезу & погана & незадовільна & задовільна & добра & відмінна \\
\hline & Естетичні якості & погані & незадовільні & задовільні & добрі & відмінні \\
\hline
\end{tabular}

найближчі терміни (через 1 місяць) при користуванні частковими знімними протезами пацієнтами 1-ї

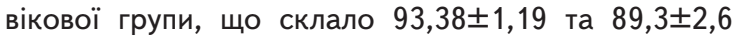

балів; також повними знімними протезами пацієнтів

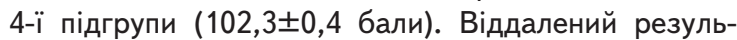
тат протезування, а саме через 6 місяців користу- 
вання частковими знімними протезами $(102,4 \pm 0,5$ та 106,8 1,9 балів) та повними знімними протезами

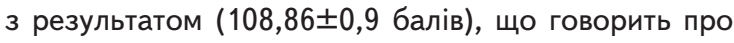
значне поліпшення ЯЖ пацієнтів.

Якість життя пацієнтів за всіма шкалами спеціального опитувальника істотно змінюється в бік поліпшення через місяць та пів року після лікування і зберігаються в часі, що пояснює стабільність лікувального ефекту, що визначається правильністю обраної ортопедичної конструкції та якісно проведеним лікуванням.

Виходячи з вищенаведених даних, якість життя пацієнтів являє собою далеко не останню позицію у якісному ортопедичному лікуванні та її необхідно враховувати в практичній діяльності лікарівстоматологів-ортопедів.

\section{Література}

1. Теоретико-методичні аспекти підвищення якості стоматологічної допомоги в Україні / А.В. Якобчук, О.В. Дементьєва, І.І. Цанько та ін. // Таврический медико-биологический вестник. - 2012. - Т. 15, № 2, ч. 3 (58). - С. 279-281.

2. Кирсанова С.В. Клинико-социальная характеристика пациентов с частичным отсутствием зубов и внедрение критериев качества жизни для оценки эффективности их лечения / С.В. Кирсанова, Э.А. Базикян, К.Г. Гуревич, Е.Г. Фабрикант / / Институт стоматологии. - 2007. - Т. 4, № 37. - С. 24-25.

3. Фастовець О.О. Щодо проблеми експертної оцінки в ортопедичній стоматології / О.О. Фастовець, О.О. Глазков / / Вісник проблем біології і медицини. - 2014. - № 3 (1). - С. 358-361.

4. Sischo L. Oral health-related quality of life: what, why, how, and future implications / L. Sischo, H.L. Broder // Journal of dental research. - 2011. - V. 90, № 11. - P. 1264-1270.

5. Лунькова Ю.С. Результати оцінки якості життя пацієнтів в динаміці ортопедичного лікування при вивихах менісків скронево-нижньощелепного суглоба / Ю.С. Лунькова, М.В. Березій, В.М. Новіков // Актуальні проблеми сучасної медицини: Вісник української медичної стоматологічної академії. - 2017. - Т. 17, вип. 2 (58). - C. 244-250.

6. Новіков В.М. Якість життя та її оцінка в процесі лікування хворих з м'язово-суглобовою дисфункцією скронево-нижньощелепних суглобів / В.М. Новіков / / Актуальні питання та проблеми розвитку стоматології на сучасному етапі: збірник наукових праць. - Полтава: ТОВ «АСМІ». - 2011. - С. 59-62.

7. Крячко А.Г. Шляхи підвищення надання якості стоматологічної допомоги / А.Г. Крячко, І.Г. Романенко / / Вісник стоматології. - 2010. - №. 4. - С. 85-94.

8. Новик А.А. Руководство по исследованию качества жизни в медицине / А.А. Новик, Т.И. Ионова. - М.: ОлМА Медиа Групп, 2007. - 320 с.

9. Якобчук А.В. Теоретико-методичні аспекти підвищення якості стоматологічної допомоги в Україні / А.В. Якобчук, О.В. Дементьєва, І.І. Цанько, О.О. Кокарь, О.В. Возний // Таврический медико-биологический вестник. - 2012. - Т. 15, № 2, ч. 3 (58). - С. 279-281.

10. Еліашова А. Вихідні умови для застосування раціональної моделі профілактики стоматологічних захворювань в Україні / А. Еліашова, Ю.О. Мочалов, О.В. Клітинська, В.З. Розлуцька // Молодий вчений. 2015. - № 6 (21), ч. 3. - С. 67-69.

11. Копейкин В.Н. Руководство по ортопедической стоматологии / В.Н. Копейкин. - М.: Медицина, 1993. $-496 \mathrm{c}$.

12. Современные методы фиксации съемных протезов: Учебное пособие для медицинских вузов / Под ред. профр. С.Д. Арутюнова, проф. В.Н. Трезубова. - М.: ТЕИС, 2003. - 123 с.

13. Quality of life assessment in clinical trials / Ed. M.J. Staquet. - Oxford University Press: Oxford, New York, Tokyo, 1998. -360 p.

И.В. Янишен, К.Ю. Андриенко, Е.О. Бережная, А.В. Погорелая, Л.Г. Салия

\section{ОЦЕНКА ЭФФЕКТИВНОСТИ ОРТОПЕДИЧЕСКОГО ЛЕЧЕНИЯ ПАЦИЕНТОВ СО СЪЕМНЫМИ КОНСТРУКЦИЯМИ ЗУБНЫХ ПРОТЕЗОВ \\ НА ОСНОВАНИИ ДАННЫХ КАЧЕСТВА ЖИЗНИ}

В данной статье представлена оценка эффективности ортопедического лечения пациентов с частичным и полным отсутствием зубов на основании данных качества жизни, выявленных в результате комплекса клинических исследований с помощью анализа ортопедических конструкций зубных протезов.

Для определения социальной характеристики пациентов и уровня их качества жизни, формирования индивидуальной анкеты-опросника были применены специальные методы исследования. Стандартизация процедуры сбора данных обеспечивалась использованием анкет-опросников.

Полученные данные подвергались процессу шкалирования. Ответы на вопросы оценивались по 5-балльной системе. Качество жизни пациентов по всем шкалам специального опросника существенно менялась в сторону улучшения через месяц и полгода после лечения и сохранялась во времени, что объясняет стабильность лечебного эффректа, а также определяется правильно выбранной ортопедической конструкции и качественно проведенным лечением. 
Таким образом, качество жизни пациентов представляет собой далеко не последнюю позицию в качественном ортопедическом лечении и ее необходимо учитывать в практической деятельности врачей-стоматологовортопедов.

КлючеВые слова: качество жизни, частичные съемные протезы, полные съемные протезы, сравнительный анализ, анкета-опросник, статистические данные.

\section{I.V. Janishen, K.Y. Andrienko, O.O. Berezhna, A.V. Pogorila, L.G. Saliya \\ ORTHOPEDIC TREATMENT'S EVALUATION OF PATIENTS USING REMOVABLE DENTURES BASED ON QUALITY OF LIFE}

This article presents an assessment of the effectiveness of orthopedic treatment of patients with partial and complete absence of teeth based on quality of life. It was identified as a result of a complex of clinical investigations with analysis of orthopedic dentures. The question of life quality, which is directly related to the health of the patient, is one of the most relevant positions in quality treatment. Evaluating the quality of life of patients is needed not only to achieve the planned rehabilitation result, but also to assess the effectiveness of the schemes and technologies used in orthopedic treatment.

A clinical examination and subjective analysis of patients who was treated by removable dentures was conducted. To determine the social characteristics of patients and their level of quality of life, and to formulate an individual questionnaire, special research methods were used. Standardization of the data collection procedure was provided using questionnaires.

As a result of surveys conducted on the early stages of development, in particular, we choose an actual questions and significant problems associated with treatment by removable dentures.

The obtained data were subjected to the scaling process, turning into scores for simplification of statistical analysis. Answers to questions were evaluated by a 5-point system.

The results of the study showed that there is less information about life's quality of patients using removable dentures, despite the high level of morbidity, which determines this problem as a priority in the system of orthopedic dentistry rehabilitation of patients with partial and complete absence of teeth.

Depending on which dentures were restorations of dental defects, it was found that the initial and final levels of quality of life were different. The quality of life of patients on all scales of the special questionnaire substantially changes in the direction of improvement in a month and a half after treatment and is stored in time, which explains the stability of the therapeutic effect, which is determined by the correctness of the chosen orthopedic design and qualitatively performed treatment.

Based on our investigations, life quality of patients is one of the main question in successful and qualitative orthopedic treatment and it should be taken into account in practical activity of orthopedic dentists.

Keywords: life quality, partial dentures, complete removable dentures, comparative analysis, questionnaire, statistical data.

\section{Контактна інформація}

Янішен Ігор Володимирович - завідувач кафедри ортопедичної стоматології, д-р мед. наук, професор, Харківський національний медичний університет

Адреса: 61022, Україна, м. Харків, просп. Науки, 4

Тел.: +38(050)323-32-71

E-mail: super opto@ukr.net

ORCID: 0000-0003-4278-5355

Андрієнко Каріна Юріївна - асистент кафедри ортопедичної стоматології, Харківський національний медичний університет

Бережна Олена Олегівна - доцент кафедри ортопедичної стоматології, Харківський національний медичний університет

Погоріла Алла Володимирівна - асистент кафедри ортопедичної стоматології, Харківський національний медичний університет

Салія Лія Гурамівна - асистент кафедри ортопедичної стоматології, Харківський національний медичний університет 